\title{
A History of Neonatal Uterine Bleeding and Its Significance
}

\author{
Giuseppe Benagiano ${ }^{1}$, Marwan Habiba ${ }^{2, * \mathbb{D}}$, Donatella Lippi ${ }^{3}$ and Ivo A. Brosens 4 \\ 1 Department of Maternal \& Child Health, Gynecology and Urology, 'Sapienza', University of Rome, \\ 00185 Rome, Italy; giuseppe.benagiano@uniroma1.it \\ 2 Department of Health Sciences, University of Leicester, University Hospitals of Leicester, \\ Leicester Royal Infirmary, Leicester LE1 5WW, UK \\ 3 Department of Experimental and Clinical Medicine, School of Sciences of Human Health, \\ University of Florence, 50139 Florence, Italy; donatella.lippi@unifi.it \\ 4 Faculty of Medicine, Catholic University of Leuven, 3000 Leuven, Belgium; ivo.brosens@med.kuleuven.be \\ * Correspondence: mah6@leicester.ac.uk
}

check for

updates

Citation: Benagiano, G.; Habiba, M.; Lippi, D.; Brosens, I.A. A History of Neonatal Uterine Bleeding and Its Significance. Reprod. Med. 2021, 2, 171-184. https://doi.org/10.3390/ reprodmed 2040018

Academic Editor: Berthold Huppertz

Received: 9 November 2021

Accepted: 9 December 2021

Published: 10 December 2021

Publisher's Note: MDPI stays neutral with regard to jurisdictional claims in published maps and institutional affiliations.

Copyright: (C) 2021 by the authors. Licensee MDPI, Basel, Switzerland. This article is an open access article distributed under the terms and conditions of the Creative Commons Attribution (CC BY) license (https:/ / creativecommons.org/licenses/by/ $4.0 /)$.

\begin{abstract}
Bleeding in newborns and young girls fascinated writers for more than a millennium. Initially, there was confusion between neonatal bleeding, early menstruation due to precocious puberty, and hemorrhage due to disease. During the 19th century descriptions appeared of what is referred to today as 'neonatal menstruation' or 'neonatal uterine bleeding'. By the turn of the century, Halban linked bleeding to active substances present during pregnancy and hypothesized that, while the maternal uterus reacts with decidua formation, the "weaker" fetal uterus reacts only with menstrual-like changes. Despite this clear description, several alternative theories endured for decades. Bleeding was believed to be due to a 'catarrhal' or neoplastic state of the genital tract, pulmonary circulatory disorder, congenital heart malformations, closure of the umbilical cord or affections of the intestine. During the 1950s, progesterone response and resistance were proposed to explain the pathogenesis of bleeding and its low incidence. The fetal endometrium is resistant to the high circulating progesterone. A decidual response is infrequent and results in menstrual shedding upon progesterone withdrawal after birth. Further research linked fetal stress consequent to pregnancy complications and post-maturity to increased incidence and preterm birth to reduced incidence of neonatal uterine bleeding.
\end{abstract}

Keywords: endometrial development; endometrial progesterone resistance; neonatal genital crisis; neonatal uterine bleeding; precocious puberty

\section{Introduction}

During the last part of the 20th century, the occurrence of a vaginal bleeding during the first days of post-natal life in some female neonates was considered a natural event caused by the rapid drop in circulating steroid hormones after birth. As it was regarded as physiological, it did not attract scientific attention. There have been no research publications on the subject between 1983 and 2013. Visible Neonatal Uterine Bleeding (NUB) affects $3-5 \%$ of neonates and is not linked to poor neonatal health [1].

Interest in NUB was renewed following the publication of a brief article raising the possibility that NUB is involved in the pathogenesis of early-onset endometriosis [2]. The subject has been explored since and a number of publications have appeared on this transient phenomenon. Of importance is the observation that NUB may be a marker or predictor of diseases occurring later in life (for details on the subject, see [3-6]).

The renewed interest stimulated our search for old and even ancient descriptions of early post-natal bleeding, its characteristics and incidence, and the various meanings that may have been attributed to it.

A cornerstone in this search was the identification of an exhaustive review of the subject, published in 1876 by Cullingworth [7], who was a Surgeon at St. Mary's Hospital in Manchester, as well as Honorary Librarian to the Manchester Medical Society. This 
allowed him access to rare manuscripts from which he was able to compile a comprehensive list of authors who commented on bleeding in neonates and infants from the 17th century onward (Table 1). An almost unique feature for its time is the precise quotation of most the publications he mentioned [8-31]. The access to original work enabled him to report most statements with accuracy.

Table 1. Cases collated by Cullingworth [7] that contained a reference to bleeding in the neonatal period. One of the articles reported in the original table could not be traced.

\begin{tabular}{|c|c|c|}
\hline & Description/Attribution of the Case & Reference \\
\hline 1 & Bleeding onset on day 8 for $10-12$ days & Bourgeois, L. (1642) [8] \\
\hline 2 & Bleeding onset on day 11 (Attributed to Martinus Weisius) & Sennertus, D. (1676) [9] \\
\hline 3 & Bleeding from birth for 15 days, then monthly till death at 3 months & Kerckringius, T. (1729) [10] \\
\hline 4 & $\begin{array}{l}\text { Bleeding onset on day 2, then monthly to } 14 \text { months (Attributed to } \\
\text { Cornelius Solingius). }\end{array}$ & Stalpartius vander Wiel, C. (1727) [11] \\
\hline 5 & Bleeding onset on day 3 . No recurrence till before death at age 3 years & \multirow{2}{*}{ Bohnius, J. (1686) [12] } \\
\hline 6 & Bleeding onset on day 4 , then monthly to the age of 12 years & \\
\hline 7 & Case of Sommers JG & Not available \\
\hline 8 & $\begin{array}{l}\text { Bleeding onset on day } 20 \text { then monthly till death at } 10 \text { months } \\
\text { (Attributed to Cummenius) }\end{array}$ & \multirow{4}{*}{ Schurigius, M. (1729) [13] } \\
\hline 9 & $\begin{array}{c}\text { Bleeding onset on day } 3 \text { for } 3 \text { days, then twice at 14-day intervals } \\
\text { (Attributed to JM Müller) }\end{array}$ & \\
\hline 10 & Bleeding onset on day 8 for 5 days (Attributed to GC Gahrliep) & \\
\hline 11 & Bleeding from birth for 5 days (Attributed to JA Hünerwolffius) & \\
\hline 12 & Bleeding onset on day 7 for 5 days & Buxtorfius, J. (1773) [14] \\
\hline 13 & Bleeding onset on day $4 / 5$ for $2 / 3$ days & Carus, C.G. (1822) [15] \\
\hline 14 & Bleeding onset on day 3 for 2 days & Plieninger, G. (1834) [16] \\
\hline 15 & Bleeding at several days of age for 10 days (Attributed to Mallat) & Boivin, M.A.V. and Dugès, A. (1834) translated by Heming, G.O. [17] \\
\hline 16 & Bleeding onset on day 2 for $6-7$ days & Dr. Truchsess of Winnenden (1836) [18] \\
\hline 17 & Bleeding onset on day 3 for 4 days & Camerer, J.W. (1834) [19] \\
\hline 18 & Bleeding onset on day 4 & Dr. Witz of Haigerloch (1835) [20] \\
\hline 19 & Bleeding onset on day 2 for $4-5$ days & Richelot, L.G. (1846) [21] \\
\hline 20 & Bleeding a few days after birth, then every 3 weeks till death at 4 years & Whitmore, W.H. (1845) [22] \\
\hline 21 & $\begin{array}{l}\text { Bleeding about } 2 \text { weeks after birth, then every } 1-3 \text { months till age } \\
44 \text { years, after which regular menses }\end{array}$ & Ashton, J.H. (1871) [23] \\
\hline 22 & Bleeding onset on day 2 for 6 days & \multirow{2}{*}{ Duncan, M. (1851) [24] } \\
\hline 23 & Bleeding onset on day 2 for 4 days (Attributed to Cunningham) & \\
\hline 24 & Bleeding onset on week 6, then monthly (Attributed to Schweldle) & Anonymous (1869) [25] \\
\hline 25 & Bleeding onset on day 3 , lasting for a brief period & Boeteiller, J. (1866) [26] \\
\hline 26 & Bleeding onset on day 5 for 3 days & \multirow{2}{*}{ Mettenheiner, C. (1869) [27] } \\
\hline 27 & Bleeding onset on day 6 (Attributed to Ritter von Rittershain) & \\
\hline 28 & Bleeding onset on day 5 for 5 days & Birchenall, J. (1865) [28] \\
\hline 29 & Bleeding onset on day 4 for 4 days & \multirow{2}{*}{ Cullingworth, C.J. (1875) [29] } \\
\hline 30 & Bleeding onset on day 5 for 2 days & \\
\hline 31 & Bleeding onset on day 5 for 4 days & Cathcart, S. (1875) [30] \\
\hline 32 & Bleeding onset on day 5 for 11 days & Dr. Kahleis of Gröbzig (1829) [31] \\
\hline
\end{tabular}

Cullingworth [7] wrote: "There occurs now and then in the female infant a discharge from the genital organs which is more or less similar in character to the menstrual fluid, and which makes its appearance within a few days after birth, most commonly, indeed, within the first week. The duration of the flow is generally from two to five days, although occasionally it has been considerably longer, and the quantity, which is sufficient to cause a stain of some size upon the napkin, amounts altogether to what would be considered an ordinary menstrual flow proportioned to the child's tender age and diminutive size". Cullingworth quotes from Vogel [32] that: "The breasts often swell at the same time, and on moderate pressure will give exit to a few drops of milky fluid". However, Cullingworth 
argued that "inasmuch as Vogel has only seen two cases himself, and gives no other authority for this statement, it is probable that he is in error in speaking of the occurrence of swelling of the breasts as frequently coincident with this haemorrhage" [7]. It is apparent that most cases collated by Cullingworth $(n=21)$ featured bleeding from day 1 to day 5 and lasted for 4-5 days $(n=10)$, which is in line with modern observations.

What Vogel described is a reaction that has been known for centuries, being first described in modern times by Czerny [33]. French-speaking authors subsequently referred to it as "crise génitale du nouveau-né" (the newborn genital crisis) [34]. The phenomenon, first studied in France by Keiffer [35], can be observed in neonates of both sexes and entails transient swelling of the mammary glands soon after birth. This may be accompanied by the secretion of few drops of milk. In English literature this was referred to as "witch's milk", a name apparently derived from a 17th century belief that, "witches" would suckle the infant's breasts and use it in magic unless the secretion is promptly and repeatedly expressed [12]. A brief description of this myth can be found in the book by Potts and Short [36].

\section{Descriptions in Ancient Texts of Vaginal Bleeding in Neonates and Infants}

The review by Cullingworth [7] formed a starting point for our exhaustive search of all historical descriptions of vaginal bleeding in neonates, infants and young children with, when available, a summary of the meaning attributed to it. We expanded this search and came across some evidence suggesting that NUB was known to at least one Medieval people: the Israelites.

It is important, at the outset, to point out that neonatal menstruation came to be recognized as a distinct entity during the first part of 19th century. Prior to this we encountered descriptions of cases of vaginal bleeding, isolated or recurrent that were reported at any time from birth to menarche. For this reason, it was not always possible to draw a clear distinction between the different presentations, or likely causes of instances of vaginal bleeding mentioned in early manuscripts.

It is likely that NUB, which is externally manifest in a female neonate, must have been observed by mothers throughout the centuries but, as it was transient and not accompanied by symptoms or illness, it may not have been reported by mothers who had far more pressing issues. Under the circumstances, such cases may not have reached the attention of the practitioners of ancient times. Indeed, in his review, Cullingworth [7] was apologetic, stating that: "it may seem that a phenomenon of so little clinical significance is scarcely worthy of being made the subject of a special paper".

In contrast, recurrent bleeding or menstruation would have been more notable. Therefore, cases of precocious puberty may have been more likely to be considered "pathological". It is to be considered that the recording of birth was unlikely to have been documented or recorded in the past.

\subsection{Maimonides (Rabbi Moshe Ben Maimon)}

It seems that the oldest inference of the existence of vaginal bleeding in a neonate or infant is contained in the Mishneh Torah, the code of Halakha (Jewish religious law) authored by Rabbi Moshe ben Maimon, known as Maimonides (a famous medieval Sephardic Jewish philosopher) towards the end of the 12th century [37]. Maimonides, in discussing the laws of ritual impurity as they apply to an adult menstruating woman, mentioned that the same laws apply to a newborn infant girl. The 12th verset of the Book of Leviticus mentions "Purification After Childbirth" and makes a distinction between a woman who gives birth to a boy or a girl [37]. In the case of the birth of a son, the woman "will be ceremonially unclean for seven days ... Then the woman must wait thirty-three days to be purified from her bleeding... If she gives birth to a daughter, for two weeks the woman will be unclean, as during her period. Then she must wait sixty-six days to be purified from her bleeding". A modern interpretation for this difference [38], suggests that the text may be implying to neonatal menstruation. Applying the rule to the newborn girl, she would 
become a zavah (a woman having had vaginal bleeding outside the days of the menstrual cycle), and-as such - in a state of impurity. Therefore, the mother, because of having been in contact with her, would be impure until the end of the newborn's seven clean days [38]. In conclusion, the Israelites of medieval times were not only aware of the existence of NUB, but they also considered it to be equivalent to a menstruation.

\subsection{Albertus Magnus and Aristotle}

According to Cullingworth [7], the first mention of NUB in the Western literature was made by the 18 th century German Catholic Dominican friar and bishop, Albertus Magnus, who was declared a Catholic saint (Saint Albert the Great) in the 20th century. In recognition of his vast knowledge, Albertus was distinguished in his lifetime as Doctor universalis and Doctor expertus and the epithet Magnus was appended to his name. Thanks to his eclectic competence (it is likely that he studied at the newly founded University of Padua), he commented on the writings of Aristotle. This was in violation of the ban imposed by the Church on the work of the great philosopher. Albertus Magnus added his own contribution from his personal observations [39].

In commenting on the eight books of Aristotle's Physics, Albertus Magnus [40,41] focused on a passage, under the title "Monstra ex superfluitate materiae fiunt tripliciter" (Monsters for excess of matter are of three types). He lists three types of circumstances capable of giving rise to "monsters": excess by number, by size, or by both. In the first case, the excess can present as a natural element manifesting itself before its time and Albertus provided an example: once, a woman showed him her daughter, born with breasts (dependentibus uberibus), hair in the groin and armpits (cum pilis inguinis et ascellarum), and menstruating since birth (patiebatur resolutionem menstruorum). In Albertus' view, the cause had to be sought in the "excessive formative heat" (propter fortitudinem caloris formantis et maturantis). What he meant was that physiological phenomena such as breast development, hair growth and menstruation, become "extraordinary" the moment they manifest out of time.

It is interesting that this case was subsequently mentioned by Joannis Georg Schenck (Joannis G. Schenckius a Grafenberg) [42] during the 17th century, and subsequently by Cullingworth [7].

The case described by Albertus Magnus seems to be the oldest recorded instance of bleeding in an infant. However, the brief description better fits as a case of precocious (perhaps, "very precocious") puberty, rather than true NUB. Obviously, nothing can be speculated as to the cause of the phenomenon.

\subsection{Louise Bourgeois}

Louise Bourgeois (called Bourset) considered herself to be a disciple of the French "barber-surgeon" Ambroise Paré, who provided service to several French Kings. Although he died in 1590, some years before Bourgeois started practicing midwifery, Paré provided an authoritative reference to her work. Louise Bourgeois was the midwife of the Maria de' Medici, Queen of France, wife of King Henry IV and regent to her son, King Louis XIII. Bourgeois was the first among early modern midwives to publish her professional experience. This came in three volumes of "Observations" [43], with the second book focusing on personal case histories [8]. Here, she mentioned the case of "a girl who, soon after birth experienced a moderate flux coming from the uterus lasting some ten days". Apparently, the story was told by the girl's mother, who Bourgeois considered "very sanguine"; but this was not considered connected to the daughter's neonatal bleeding. In fact, Bourgeois states that she had never previously seen similar cases and that the cause was obscure. She cited the possibility that "extreme 'heat' made (the uterus) furious" and therefore capable of expelling blood that would otherwise have remained inside. As "proof' of her theory, Bourgeois describes that "towards the end" the bleeding "became putrid". She concluded that "at any rate, these are things against nature". Thus, the 
reported observation was accompanied by explanations that were in line with the prevailing conceptions of pubertal development at the time.

\subsection{Additional Early Mentions}

In 17th-century Germany, Georg F. Franck von Franckenau (Georgius Fridericus Francus de Frankenau) [44] became famous for his "Satyrae medicae" (Medical Satires), collections of curiosities published between the 1670s and 1680s, with short descriptions of the marvels of nature, humans included. He discounted the role of demons but admitted that explaining strange cases is difficult. For Franck, these phenomena represented signs of nature's fertility and richness, or examples of pathologies that - at any rate-have natural causes [45]. The sixth satire deals with "menstruation", including those in men, very young children and old women. He provided a list of rarer cases (rariora) of young girls, including newborn babies, who have had menses. Drawing from eye-witness testimony he mentioned cases of bleeding in a 2-day-old infant and in a newborn (recens nata).

Around the same time, Johan D. Bohn (Johannes D. Bohnius) [12], stated that menses usually begin around age 14 but that exceptions include instances where bleeding started at 12,11, 9, 8, 6 years and even on the day of birth (imo ab ipso nativitatis die). Bohn quoted Bourgeois and described two cases of infants menstruating on days 4 and 5 of life. The first baby girl died aged 3 because of vaginal and gengival (per pudenda aeque ac gingivas) hemorrhage. The second became "menopausal" at age 12.

Theodor Kerckring (Theodorus Kerckringius) [10], in his Opera Omnia Anatomica, dedicated a full Observatio (LXXXVII) to menses occurring on the very day of birth (Menstrua ab ipso nativitatis die fluentia). He quoted the observations of several authorities who claimed to have witnessed menarche at early age: Fernelius, at 8 and 9 years; Schenck and Herculis, at 5 years; and Tulpius, between 4 and 8 years.

Kerckring stated that he had not personally seen menses appearing in the first days of life, but provided what he heard from a trustworthy person: "On 14 October 1668 was brought to the attention of a practitioner in Amsterdam a 3.5 month-old baby girl." The mother, "taken by anger during pregnancy, had been destabilized to such an extent that her period returned regularly" in spite of gestation. At the end of pregnancy bleeding lasted 15 days and, while still bleeding, she gave birth to a baby girl who herself started losing blood on the day of birth and continued for 15 days. Menses returned to the baby after 1, 2 and 3 months and, on the 4th, the infant died of "epilepsy". Kerckring ended the description mentioning that he saw a "nine-year-old noble girl" with epilepsy (epilepsiae obnoxia) and regular menses, in this way he made a connection between the two conditions.

A further brief summary of the knowledge that existed during the 17th century was provided by Daniel Sennert (Danielis Sennertius) [9]. Sennert did not present any personal observation but reiterated the cases of Albertus Magnus, Martinus Weisius, Hercules Saxoniæ, Johannes Schenkius and Johannes Fernelius. These included neonatal bleeding and early menarche.

During the second part of the 18th century, Buxtors (Johannes Buxtorsius) [14] presented a case from Switzerland in his "Commentarii". Buxtors recorded having observed a "newborn girl who in her seventh day of life menstruated for 5 days without any damage and, one year later was again menstruated without problems".

In British literature, neonatal bleeding is mentioned in the comprehensive textbook of Pediatrics by Michael Underwood in 1797 [46]. This includes a clear description of NUB but no additional personal observations. Underwood states that: "female infants have sometimes such a discharge from the vagina a few days after birth, which appears to be of no consequence". He ventured to suggest a possible treatment: "Should it, however, on any account, be thought necessary to prescribe something, a little testaceous powder, or magnesia, according to the state of the bowels, will be sufficiently astringent, as the discharge always disappears in a few days". 


\subsection{Martin Schurig (D. Martinus Schurigius)}

In the book Parthenologia Historico-Medica, published in 1729, Martin Schurig (D. Martinus Schurigius) [13] dedicated a whole section to a detailed discussion of menstruation. In relation to the age of menarche, he concluded that there is a consensus that the first menstruation occurs at 14-15 years of age. In Chapter V of the book, entitled "De Menstruationis termino" (On the limits of menstruation) under "Precocious menstruation" he lists authors who described cases of bleeding starting in girls (puellae) from 1-12 years of age. Schurig stated that in these instances the appearance of bleeding should be considered as the beginning of puberty. This seems in line with the modern understanding "precocious puberty".

When he addressed cases of bleeding in newly born girls (puellis recem natis), Schurig recounted published cases he had become aware of, starting with the two cases described by Bohn [12], followed by a case he attributed to Schenck [42] of a girl who was born with developed breasts, axillary and pubic hair and who menstruated during the first day of life. However, this may be the same case described by Albertus Magnus [40,41]. Schurig reported the case attributed to Cummen (Alardus Hermannus Cummenus) of a newborn girl who, from the day of birth, began to bleed. Afterwards "the flux stopped after a few days, but returned after a month, then monthly until the ninth month". On the 10th month the girl died of smallpox. The following case summarized by Schurig was the first attributed to Hünerwolff (Jacobus Augustinus Hünerwolffius, Physicus Arnastadiensis) of "a woman was following her husband in the army and delivered in a military camp; on her fifth day, the baby girl, after intense crying, started bleeding from the womb; the bleeding quickly waned, and the baby was able to rest comfortably".

The list continues with the descriptions attributed to Müller (Johannes Matthias Müllerus) of a baby girl who experienced rumbling in the abdomen on the 3rd day after birth and a flow of blood from the "uterculo" on the following day. Thereafter, the labia became turgid and the flow of blood became partially clotted, stopping after 14 days. Bleeding then returned 3 days later and finally ended. Another case mentioned by Schurig was that attributed to Gahrliep (Gustavus Casimirus Gahrliepus) of "a five-day-old baby girl who had never urinated, who had been crying for three days when a whitish and viscid secretion from the vagina became evident; slowly this secretion became increasingly reddish until it looked very much like blood, lasting for five successive days, then gradually diminishing in amount". Schurig reported the case described by Kerckring [10] of a baby girl from Amsterdam. This may be the same case described by Cummen.

Schurig included cases from French literature. The first was in a book by Jean Baptiste Verdue [47], who reported an observation by Cornelius Solingius and commented on by Cornelius Stalpius van der Wiel [11] of a 14-month-old baby who bled in great quantity twice after birth. The bleeding was excessive considering her size. The second case was that described by Louise Bourgeois [8].

\subsection{Franz Carl Nägele}

In 1812 the German obstetrician Nägele published a comprehensive textbook of obstetrics and diseases of women [48], in which he critically reviewed reported cases of "menstruation-like bleeding" occurring before menarche. Nägele expressed doubts about these reports, arguing that they were usually based on insufficiently substantiated testimonies. In line with beliefs popular at the time and adopting a similar approach to that of Albertus Magnus, Nägele aimed to evaluate whether these cases should be designated, in accordance with Aristotle, as "monstra" (i.e., prodigious cases due to impurity of blood and sperm), or true "pathological phenomena". Nägele concluded that hemorrhages at birth do not represent true menstruation and, in line with the nascent scientific approach, he tried to distinguish cases of simple post-natal bleeding from those in which there were other diagnostic elements. These may reside in general aspects of the infant girl with precise attributes, as in a case of a 4-year-old girl who looked 18. His skepticism goes as far 
as to state that he regarded many of the cases recorded as precocious menstruation, as the fruit of credulity, or as fables invented to please.

Nägele's approach was to critically examine each reported case. He referred to a book titled Opera Practica, by Herculis Saxoniae (an Italian physician who lived during the second half of the 16th century and was Professor of Medical Practice at the University of Padua) [49], as the source of the story of a child menstruating since birth whom Herculis compared to an animal that is born with wings and flies immediately. Nägele mentioned a case of vaginal bleeding in a 1-year-old infant and in a 3-year-old baby who died at the age of 5 years. Finally, he described bleeding in one newborn, which he considered not to be a menstruation, but that it more likely originated from the urinary tract, or the bowel. This, however, is probably the only description of a case of true NUB case.

\section{The Identification of Vaginal Bleeding in Neonates as a Specific Entity}

As discussed, several cases have been described over the centuries of what we can today label as neonatal uterine bleeding. However, these were usually mixed with cases of precocious puberty, or with bleeding due to disease. Almost invariably, the physiological nature of the phenomenon was overlooked.

\subsection{Early Descriptions}

The first clearly detailed case of NUB, as recognized today, is that reported by Carus in 1822 [15]. In a brief paragraph he provided a neat description. A mother who had already delivered twice was "admitted on 21 March 1819 with labor, in a local institution for delivery. Within a short time, a normal female baby was born. On $23 \mathrm{March}$, the mother suffered from a stronger vaginal bleeding, which stopped after drinking several cups of cinnamon tea. On 25 March, a release of mucus from the vagina was observed in the baby, who was not breastfed. On $26 \mathrm{March}$, there were drops of blood (from the vagina). This very small bleeding persisted until 27 March and stopped completely on $28 \mathrm{March}$. The baby was quite healthy during this process, which was quite similar to a menstruation, starting first with mucus secretion like a premonitory signal of the subsequent blood flow and she was released from the delivery institution together with the mother". Carus was unable to obtain follow-up of the baby.

The second case was presented in 1829 by a Dr. Kahleis [31], who mentioned when discussing menstruations continuing until late age (e.g., 70 years), that he also saw a case who was exactly the opposite. He describes a "baby girl aged 8 days who had a three day history of vaginal blood loss equivalent to three teaspoons". It seems that, within a decade, the topic caught more attention from writers of the time. Boivin and Dugès [17], in their book on Diseases of the Uterus, published in 1834, mentioned a case of neonatal hemorrhage in which a few days after birth "some blood was observed several times, in the clothes, which the nurse attributed to haemorrhage of the umbilical cord. In fifteen days a very long coagulum was discovered in the vagina. The blood continued for more than 10 days". Interestingly, the baby had tender, enlarged breasts. Then, in 1835, Billard [50] wrote: "I have found twice blood, effused and caught in a clot, in the uterine cavity of infants deceased a few days after birth".

Around the same time, several additional cases were succinctly presented in the Medicinal correspondence leaflet of the Württemberg Medical Association. The first of these presentations was made in 1834 by Plieninger [16], followed by Camerer in Langenau [19], who believed that the phenomenon might be related to the ligature of the cord when still pulsating and before the pulmonary circulation is well established. He suggests that this could cause downward streaming of blood into the uterus. Two more cases were described by Witz [20] and Truchsess in Winnenden [18]. Two publications in German appeared: one in 1846 dealt with the discharge of blood from the vagina in little girls [21]; and the second, in 1869, discussed congenital or premature bleeding from the female genitals [27]. 
In 1845, the Northern Journal of Medicine published what may be the first case from the United States of "of menstruation in an infant, commencing a few days after birth" [22]. This was followed by a case published anonymously in 1869 and attributed to Dr Schwelder of New York [25].

Several cases were also published in Britain: the first appeared in 1851 and described the presence of "spurious menstruation" in newly born infants [24]. Another case was added in 1865 [28]. Further cases were described in the following decade [23,29,30].

Boetellier in 1866 [26] presented one case from France of a 3-day-old baby girl who bled during a short period. The newborn looked healthy but presented a clear vertical facial asymmetry and a clubfoot varus.

In 1876, Cullingworth's milestone review [7] helped the dissemination of knowledge about NUB. In the following years, additional sporadic cases continued to appear in literature: in 1893, Engström [51] reported a case from 1888 in a prematurely born child in Finland. He noticed "a bloody-colored slimy discharge from the vagina... on the evening of the same day of birth". The following day he found "tiny, bloody discharge from the vagina mixed with mucus". This continued for 8 days. Engström stressed that the condition of the newborn was always quite normal, that he excluded any pathological cause and concluded that the bleeding was perhaps menstrual.

Several cases of bloody discharge from the vulva and vagina by newborn girls have been reported in Europe around the turn of the century. Unfortunately, a few of the early references could not be verified, e.g., Busey [52], or did not report new relevant cases, e.g., Ferraresi [53] and Vetere [54]. Setting these reports aside, we were able to identify several other cases reported by Kouindjy [55], Jardine [56], Alfieri [57], Zappert [58], Purefoy and Castor [59] and Dewar [60].

In commenting on the case by Jardine [56], Williams [61] made a series of interesting observations. He indicated that the nature of NUB had been identified 120 years previously. He wrote that "slight sanious vaginal discharge at or about birth is of such common occurrence that it may be regarded as physiological" and that it "may be more correctly regarded as prototypes of the menstrual flux". McWalter [62] viewed such bleeding as "the perfect miniature representation of mature menstruation of womanhood", and that there was a consensus that the phenomenon was the consequence of "premature uterine activity". Purefoy and Castor agreed and described two cases of "red, vaginal discharge, having the characters of menstrual fluid" adding that "in both cases the child's condition did not afford any indication for treatment" [59].

In 1907, Drake [63] from the United States, described another case of a normal neonate who had vaginal bleeding that lasted for 2 days and then declined. Intriguingly, Drake did not refer to the abundant literature from Europe, or to previous contributions from the USA. He writes that the origin of the phenomenon may rest "as Holt points out, in the change of the character of the blood itself and in the radical change in the circulation of the blood produced by ligation of the cord". In his textbook of 1897, Holt wrote that hemorrhage from newborn genitals is not infrequent, is rarely serious and that it should not be regarded as precocious menstruation [64]. In 1921, Emil Novak provided a comprehensive summary of the knowledge up to his time in his book "Menstruation and its disorders" [65] but, unfortunately, not all the references he cites are traceable.

Early observations have several common features: first, in a number of cases, the bleeding is preceded by mucoid secretion, followed within a day or so by bloody discoloration before a small amount of blood is seen at the vulva. The bleeding which is initially bright red, becomes dark brown or chocolate colored. When observed under the microscope it presents no abnormality [66]. Although the bleeding is usually transitory, cases were described where it recurs periodically. Williams reported that in a few instances, bleeding "merge into regular menstruation, generally with the appearance of other manifestations of precocious sexual development" [61]. Once again, NUB and precocious puberty were viewed together. Kouindjy presented three cases of NUB, two of which were from consecutive pregnancies of the same woman [55]. 
All early observations conform to Collingsworth's statement [7] that "No case of hemorrhage from the female genital organs in the newly born bas hitherto been recorded in which the general health had been seriously impaired thereby, and still less which has been attended with a fatal result".

In relation to nomenclature, Krönig proposed the term 'Metrorrhagia neonatorum' to describe NUB, but this was not widely adopted [67].

\subsection{Frequency}

The frequency of NUB was one of the first characteristics to be evaluated. Cullingworth [7] juxtaposed Nägele's [48] skepticism with an 'anonymous correspondence in the British Medical Journal which argued that "any old, experienced nurse will be able to tell that the colored discharge from young girls, is an almost daily occurrence". But it is unclear that both writers were referring to the same observation. Schukowsky reported NUB in $0.18 \%$ cases from a large series of 20,000 newborn girls [66]. Renouf reported visible NUB in $2.6 \%$ out of 721 cases [34]. Zacharias reported NUB in $2.5 \%$ of 400 newborn girls [68]. Billard identified coagulated blood in the uterus at autopsy in 2 out of 700 cases [50]. The incidence was higher ( 8 out of 21 cases) in the autopsy series by Halban [69], who commented that microscopy was more sensitive in identifying red blood cells in the vaginal secretion. Based on the experience of pediatricians and nurses, Lisi [70] estimated that the frequency of bleeding was around $2-3 \%$ and that the average duration of blood loss was 24-48 $\mathrm{h}$ and less often was $4-6$ days. Importantly, bleeding is not accompanied by changes in the general state of health or by manifestations of pain.

Systematic reports of the frequency of NUB became available in the 1970s and 1980s. In a study involving 30 neonates chosen ad hoc, Andreoli and Simonetta reported occult bleeding in 29 cases and visible bleeding in 10 cases [71]. However, the small sample size hinders generalizability. Levy et al. reported NUB in 48 of $1057(4.5 \%)$ healthy female babies [72]. Zubovich reported macroscopic (7.8\%) and microscopic $(66 \%)$ bleeding in a cohort of 541 newborn girls [73]. Kaiser et al., reported visible NUB in 5.3\% and hemoglobin detection in $61.3 \%$ out of 153 neonates [74]. Huber reported visible bleeding in $3.3 \%$ and occult bleeding in $25.4 \%$ during the first week post-partum in a study involving 350 newborn girls [75]. In the largest ever study, involving all female babies born in 1979 at the University of Novi Sad, in Serbia $(n=2477)$ [76], visible NUB was present in $3.9 \%$ newborn girls. NUB was reported in one case $(0.8 \%)$ amongst preterm births $(n=126), 85(3.8 \%)$ of term births $(n=2241)$ and $10(9.1 \%)$ of post-term $(n=110)$ babies. Although the cases may not be totally comparable, the figures suggest an incidence of $208 / 4578$ cases $(4.5 \%)$.

\subsection{Associated Pathology}

Aside from the assumption of a "very precocious puberty", pathological associations were observed in only a few cases: In 1898, a French weekly, reported in a short paragraph, that Dóleris had observed "a small, but serious, epidemic of vulvar hemorrhages in newborn babies" [77]. Dóleris reported five cases occurring during a short period of time. The genital hemorrhage was fatal in four out of the five cases. Only one autopsy was performed, and this showed sterile blood and a streptococcus infection of the liver. The causes of death in the other four cases were undetermined. However, the report stated that "these neonatal bleedings are considered physiological".

Frew reported the case of a healthy female who was born at home and who, on the following day, had "general convulsive twitchings of the muscles all over the body" on the following day. There were no other abnormal findings [78]. On the second day, the nurse observed a "discharge of blood" that "was seen to be vaginal in origin" that lasted for 3 days. Lisi published the case of a neonate in whom scarce blood loss was noted on day 2 after birth [70]. Initially, this was believed to be intestinal, but the blood loss increased, and some seemed to originate from the uterus. The baby died on day 8 . The autopsy showed bowel necrosis accompanied by a hemorrhagic infiltration of the endometrium, 
hematometra and left hematosalpinx. It could be speculated that this may have been primarily a case of necrotizing enterocolitis. Our modern understanding suggests that associated pathology in the above cases is likely to have a different origin.

\subsection{The Work of Joseph Halban}

Halban was an Austrian obstetrician and gynecologist who initially worked under the great gynecological surgeon Friedrich Schauta, before becoming head of gynecology at the Wiedner Spital in Vienna. He pioneered the field of reproductive endocrinology, with emphasis on placental functions [79]. In 1904 he presented a paper "on fetal menstruation and its meaning" to the 76th assembly of German naturalists and doctors. In the published summary, he described changes in the uterus occurring around month 8 of gestation as follows: "Histologically, a significant hyperemia can be demonstrated, with the mucosa undergoing changes quite analogous to those of the menstrual stage in adults" [80]. Halban reported that this reaction is not uniform and that a variety of features can be observed depending on its strength. These encompass "all the stages of pre-menstrual hyperemia, up to sub-epithelial hemorrhages and free blood leakage into the uterine cavity. Almost always blood can be detected only with the microscope" [80]. Halban's view was that even the most advanced reaction that leads to newborn genital bleeding is a physiological not a pathological process.

With great intuition, Halban stated that "these changes must be interpreted as a reaction to active substances present during pregnancy. While the maternal uterus reacts with decidua formation, the weaker fetal uterus reaction leads only to menstrual-like changes" [80]. It took 50 years for the work of Rosa [81], who observed that only during the last month of pregnancy the endometrium shows evidence of pre-decidualization, and of Ober and Bernstein [82], who documented that in about two thirds of female fetuses near term the endometrium does not respond to the very high levels of circulating progesterone, to confirm this intuition. Halban was the first to hypothesize that the active placental substances are "some kind of internal secretion from this organ" and that they are then "secreted in the same way to both mother and fetus".

Thus, Halban postulated: (1) a hormonal production by the placenta; (2) the action that these hormonal substances have on fetal endometrium; (3) that this action exists in a variety of degrees; (4) the existence of various final stages of endometrial maturation that depend on the degree of reactivity of the uterine mucosa. In this way, Halban provided the basis for the occurrence of NUB and for it being manifest in only a small percentage of newborns.

In 1904, Halban also published a full article on the modifications produced in fetal organs by pregnancy [69]. These observations were based on histological examination of 21 uteri of newborn girls. He described a two-stage process: first, there is hyperemia of the endometrium; this is followed by the appearance of small subepithelial overflows with breakdown of the integrity of the superficial epithelium. He ruled out local inflammatory lesions or any role for the ovary in the observed endometrial features and concluded that neonatal bleeding should be interpreted as a non-typical reaction of the organ to substances circulating in the fetus during intrauterine life. Given the limited knowledge available at the time, this must be seen as a testimony of his acumen.

\section{Conclusions}

After centuries of precise descriptions of a phenomenon that seems to have fascinated physicians, midwives and even philosophers, the occurrence of neonatal menstruation has now been fully recognized and linked to a hindered endometrial maturation due to a resistance to progesterone action [83]. However, many of its associations require further investigation. It is perhaps surprising that almost a millennium was required for there to evolve a clear distinction between true neonatal uterine bleeding (a physiological phenomenon), precocious puberty and other rare causes of genital or intestinal bleeding. 
From a historical point of view, clear descriptions of what we today call 'neonatal menstruation' or 'neonatal uterine bleeding', began to appear during the first part of the 19th century, and by 1904 , Halban $[69,80]$ intuitively concluded that NUB is due to a reaction to active placental substances produced during pregnancy. He further hypothesized that, while the maternal uterus reacts with decidua formation, the weaker fetal uterus reacts only with menstrual-like changes.

An explanation of the pathogenesis of NUB, as well as of its relative rarity, was offered in the mid 19th century by Rosa [81] and by Ober and Bernstein [82], who suggested that fetal endometrium is resistant to the action of the high concentrations of circulating progesterone and that it responds to the hormone in only a few cases. Understanding the endometrial response, however, is further complicated because of the higher incidence of occult bleeding and because of the impact of gestational age and in-utero stressors.

Author Contributions: G.B.: conceived the idea and led the writing of the manuscript. M.H.: led the literature search and contributed to the drafts. D.L.: led the interpretation of old texts and contributed to the draft. I.A.B.: conceived the idea and supplemented part of the literature. All authors have read and agreed to the published version of the manuscript.

Funding: This research did not receive grants from any funding agency in the public, commercial or not-for-profit sectors.

Institutional Review Board Statement: Not applicable.

Informed Consent Statement: Not applicable.

Acknowledgments: We wish to acknowledge that this review would not have been possible without the work of librarians and funding bodies who placed a large collection of old texts and made it available for researchers.

Conflicts of Interest: The authors have no conflicts of interest.

\section{References}

1. Brosens, I.; Benagiano, G. Is neonatal uterine bleeding involved in the pathogenesis of endometriosis as a source of stem cells? Fertil. Steril. 2013, 100, 622-623. [CrossRef] [PubMed]

2. Brosens, I.; Brosens, J.J.; Benagiano, G. Neonatal uterine bleeding as an antecedent of pelvic endometriosis. Hum. Reprod. 2013, 28, 2893-2897. [CrossRef] [PubMed]

3. Dekker, J.; Hooijerb, I.; Ketc, H.; Vejnović, A.; Benagiano, G.; Brosens, I.; Mijatovic, V. Neonatal uterine bleedings: An ignored sign, but a possible cause for early-onset endometriosis. A systematic review. Biomed. Hub. 2021, 6, 6-16. [CrossRef] [PubMed]

4. Gargett, E.; Schwab, K.E.; Puttemans, P.; Brosens, J.J.; Benagiano, G.; Brosens, I. Potential role of endometrial stem/progenitor cells in the pathogenesis of early-onset endometriosis. Mol. Hum. Reprod. 2014, 20, 591-598. [CrossRef]

5. Brosens, I.; Benagiano, G.; Brosens, J.J. The potential perinatal origin of placentation disorders in the young primigravida. Am. J. Obstet. Gynecol. 2015, 212, 580-585. [CrossRef]

6. Bianchi, P.; Benagiano, G.; Brosens, I. Promoting awareness of neonatal menstruation: An important, yet neglected reproductive phenomenon. Gynecol. Endocrinol. 2017, 33, 173-178. [CrossRef]

7. Cullingworth, C.J. Hemorrhage from the Genital Organs in the Recently Born Female Child. In The Liverpool Manchester Medical and Surgical Reports; Wallace, J., Ed.; JE Cornish: Manchester, UK, 1876; pp. 43-57.

8. Bourgeois, L. Observations Diverses, sur la Sterilité, perte de Fruict, Foecondité, Accouchements, et Maladies des Femmes, et Enfants Nouveaux Naiz [Various Observations on Sterility, Abortion, Fecundity, Delivery, and Women's Diseases and Newborn Babies]; Abraham Saugrain: Paris, France, 1617; p. 23.

9. Sennert, D. De mensibus nimis mature fluentibus. In Operum Tomus Tertius. Editio Novissima [Of menses Released Too Soon. In: Opus, Volume Three. Newest Edition]; Sumptibus Joannis Antonius Huguetan: Leiden, The Netherlands, 1676; p. 659.

10. Kerckring, T. Opera Omnia Anatomica: Continentia Specilegium Anatomicum, Osteogeniam foetuum, nec non Anthropogeniae Ichnographiam: Accuratissimis Figuris Aeri Incisis Illustrata [Complete Antomical Works: Including Anatomical Collection, Osteogenesis of the Fetus; As Well as Ichnography of Human Development: Most Accurately Illustrated with Copper Incisions]; F. Corn. Boutesteyn: Leiden, The Netherlands, $1717 ;$ p. 168.

11. Stalpart van der Wiel, C. Observationum Rariorum Medic. Anatomic. Chirurgicarum. Centuria Prior, Accedit de Unicornu Dissertatio [On the Very Rare Observations in Anatomy, Medicine and Surgery. A Century Earlier, He Produced a Dissertation on the Unicorn]; J. à Kerckhem: Leiden, The Netherlands, 1727. 
12. Bohn, D.J. Circulus Anatomico-Physiologicus, Seu Oeconomia Corporis Animalis: Hoc est, Cogitata, Functionum Animalium Potissimarum Formalitatem \& Causas Concernentia [Anatomico-Physiological System, or of the Functioning of the Body of an Animal: That Is, Thoughts Concerning the Causes and Mechanisms of Animal Functions]; Gleditsch: Lipsiae, Germany, 1686.

13. Schurig, M. Parthenologia Historico-Medica, Hoc Est, Virginitatis Consideratio qua ad eam Pertinentes Pubertas and Menstruatio, cum Ipsarum Maturitate; Item Varia de Insolitis Mensiums viis Atque Dubiis Virginitatis Signis; nec non de Partium Genitalium Muliebrum; pro Virginitatis Custodia, Olim Instituta Consutione et Infibulatione Variis Atque Selectis Observationibus cum Indice Locupletissimo TRADUNTUR [Historico-Medical Parthenology, That Is to Say, Considerations on Virginity and Everything Which Pertaisn to Puberty E Menstruation, Followed by Maturity; And Also on Various and Rare Ways of Menstruation; And on Doubts about Signs of Verginity, As Well as on the Female Genital Tract; About the Preservation of Virginity Once Performed by Sewing and Infibulation; (All These Items) Are Presented through Various and Selected Observations, with a Very Accurate Index]; Christophori Hekelii B. Filium: Dresden/Leipzig, Germany, 1729; pp. 20-21.

14. Buxtors, J. Commentarii de Rebus in Scientia Naturali et Medicina Gestis [Commentary on Topics of Natural Sciences and Medicine of Pregnancy]; Iohannes Fridericum Gleditsch: Leipzig, Germany, 1773; Volume XIX, p. 527.

15. Carus, C.G. Aerztliche Miscellen zur Lehre von den Krankheiten neugeborner Kinder (Item IV) [Medical miscellaneous for teaching the diseases of newborn children]. Z. Natür-Und Heilkd. 1822, 2, 98-107.

16. Plieninger, G. Blutabgang aus den Geschlechtstheilen eines Neugeborenen Mädchens [Bloodloss from the Genital Parts of a Newborn Girl]; Medicinisches Correspondez-Blatt des Württembergischen Ärztlichen Vereine; Verlag der Fr. Brodhag'shen Buchhandlung: Stuttgart, Germany, 1834; p. 200.

17. Boivin, M.A.V.; Dugès, A. A Practical Treatise on the Diseases of the Uterus and Its Appendages; Translated from the French with Copious Notes; Heming, G.O., Translator; Sherwood, Gilbert, and Piper: London, UK, 1834; p. 395.

18. Truchsess in Winnenden. Dr. Blutsabgang aus den Geschlechtstheilen zweier Mädchen [Blood Discharge from the Genitals of Two Girls]; Medicinisches Correspondez-Blatt des Württembergischen Ärztlichen Vereines; Verlag der Fr. Brodhag'shen Buchhandlung: Stuttgart, Germany, 1836; Volume 6, pp. 400-402.

19. Camerer JW in Langenau (Cammerer). Ein Beitrag zur Physio-Pathologie der Blutnngen aus den Geschlechtsthellen Neugeborner Mädchen [A Contribution to the Physio-Pathology of Bleeding from the Genitals of Newborn Girls]; Medicinisches Correspondez-Blatt des Württembergischen Ärztlichen Vereines: Stuttgart, Germany, 1835; Volume 4, p. 88.

20. Witz zu Haigerloch. Fall Einer Menstruationsähnlichen Blutung aus der Scheide, bei Einen vier Tage Alten kind [A Case of Menstrual-like Bleeding from the Vagina in a Four-Day-Old child]; Medicinisches Correspondez-Blatt des Württembergischen Ärztlichen Vereines; Verlag der Fr. Brodhag'shen Buchhandlung: Stuttgart, Germany, 1835; p. 550.

21. Richelot, L.G. Über die Blutausflüsse aus der Scheide bei kleinen Mädchen. [About the discharge of blood from the vagina in little girls]. J. Kinderkrankh. Berl. 1846, V.I., 70.

22. Whitmore, W.H. Case of menstruation in an infant, commencing a few days after birth. North J. Med. 1845, 15, 70.

23. Ashton, J.H. Early menstruation (letter). Lancet 1871, 1, 366.

24. Duncan, M. Spurious menstruation in newly-born infants. Mon. J. Med. Sci. 1851, 5, 493.

25. Anonymous (Case Attributed to Dr. Schwelder of New York). Abstracts. Am. J. Obstet. Dis. Women Child. 1869, 1, $164-175$.

26. Boetellier, J. Hémorrhagie per le vagin [Hemorrhage from the vagina]. La Lancette Française-Gaz. Des Hôpitaux Civ. Mil. 1866, 39, 542-543.

27. Mettenheimer, C. Angeborene oder sehr früh eingetretene Blutung aus den weiblichen Genitalien. [Congenital or premature bleeding from the female genitals]. J. Kinderkrankh. Erlangen 1869, LII, 3-6.

28. Birchenell, J. Sanguineous discharge from the vagina of an infant. BMJ 1865, 25, 550. [CrossRef]

29. Cullingworth, C.J. Early menstruation (letter). BMJ 1875, 2, 514.

30. Cathcart, S. Early menstruation. BMJ 1875, 2, 447.

31. Kahleis zu Gröbzig. Späte catamenien [Late catamenia]. J. Pract. Heilkunde 1829, 2, 85.

32. Vogel, A. A Practical Treatise on the Diseases of Children; Raphael, H., Ed.; Translators; D. Appleton \& CO.: New York, NY, USA, $1870 ;$ p. 471.

33. Czerny, A. Über die Brustdrüsensecretion beim Neugeborenen und über das Verhältniss der sogenannten Colostrumkörperchen zur Milchsecretion [On the Secretion of the Mammary Glands in the Newborn and the Ratio of the So-Called Colostrum Bodies to Milk Secretion]; Festschrift für Henoch; Hirschwald Verlag: Berlin, Germany, 1890; pp. 194-204.

34. Renouf, C. La Crise Génitale et les Manifestations Connexes chez le Fœtus et le Nouveaux-Né. Ph.D. Thesis, Verlag Nicht Ermittelbar, Paris, France, 1905.

35. Keiffer, D. La glande mammaire chez le foetus et chez le nourrison [The mammary gland in the fetus and infant]. Ann. Société Gynécol. et d'Obstétrique France 1902, 57, 232.

36. Potts, M.; Short, R. Ever Since Adam and Eve. The Evolution of Human Sexuality; Cambridge University Press: Cambridge, UK, 1999; p. 145.

37. Rabbi Moshe ben Maimon (Maimonides); Translated by Eliyahu Touger. The Mishneh Torah. Jerusalem: Moznaim Pub Corp. 2010. Leviticus 12. pp. 1-5. Available online: https://margmowczko.com/purification-after-giving-birth-leviticus-12/\#_ftn1 (accessed on 7 December 2021).

38. Meacham, T. A suggested commentary for the doubling of days of impurity and purity for the woman who births a daughter. Shnatôn: An Annual for Biblical and Ancient Near Eastern Studies. JSTOR 1997, 11, 153-166. 
39. Weisheipl, J.A. The life and works of St. Albert the Great. In Albertus Magnus and the Sciences: Commemorative Essays, Studies and Texts; Pontifical Institute of Mediaeval Studies: Toronto, ON, Canada, 1980; Volume 49, p. 46.

40. Albertus, M. Opera Omnia. [Complete Works]; Physicorum, L., VIII, Tractatus, I.I., Borgnet, A., Eds.; Ludovicum Vives: Paris, France, 1890; Volume 3, p. 167.

41. Albertus, M. Original Manuscript of Opera Omnia. Kislak Center for Special Collections; Rare Books and Manuscripts; University of Pennsylvania: Philadelphia, PA, USA, 1951; Lawrence J. Schoenberg Collection LJS no 234, page c. 23r, Column A.

42. Schenk von Grafenberg, J. Observationum Medicarum Rariorum, Libri VI, Observ. IVI [On Rare Medical Observations Book 7]; Sumptibus Joannis Beyeri: Frankfurt, Germany, 1665; p. 304.

43. Worth-Stylianou, V. Louise Bourgeois: An Early Modern Midwife's Observations on Female Infertility. Women's Stud. 2020, 49, 281-295. [CrossRef]

44. Franck de Frankenau, G.F. Satyrae Medicae XX. Quibus Accedunt Dissertationes VI. Varii Simulque Rarioris Argumenti, Una Cum Oratione de Studiorum Noxa, Editae ab Autoris Filio Georgio Friderico Franck de Franckenau [Medical Satyrs, X.X.; To Which 6 Dissertations Are Added. Description of Various and Very Rare Stories, Together with a Description of Studies of Diseases, PUBLISHED by the author's Son, George Frederick Franck de Franckenau]; Apud Maur. Georg Weidmann: Leipzig, Germany, 1722.

45. Kivistö, S. GF von Franckenau's Satyra sexta (1674) on Male Menstruation and Female Testicles. In The Trouble with Ribs: Women, Men and Gender in Early Modern Europe; Korhonen, A., Lowe, K., Eds.; COLLeGIUM: Studies across Disciplines in the Humanities and Social Sciences: Helsinki, Finland, 2007; pp. 82-102.

46. Underwood, M.A. Treatise on the Disorders of Childhood and Management of Infants from tbe Birth (In 8 Volumes); J Mathews: London, UK, 1797; Volume II, p. 143.

47. Verdue, J.B. Suite de la Pathologie de Chirurgie [Addendum to Surgical Pathology]; Chez Laurent d'Houry: Paris, France, 1710; p. 1114, Chapter 46.

48. Nägele, F.C. Erfahrungen und Abhandlungen aus dem Gebiethe der Krankheiten des weiblichen Geschlechtes: Nebst Grundzügen einer Methodenlehre der Geburtshülfe [Experiences and Treatises in the Field of Diseases of the Female Sex: Together with the Basics of a Methodology of Obstetrics]; Löffler: Mannheim, Germany, 1812; pp. 318-328.

49. di Sassonia, E. Opera Practica, Quibus hac Octava Editione Accesserunt quae Pagina versa Indicantur. [Practical Works, To Which with This Eight Edition the Things Were Added Which Are Indicated Overleaf]; Typographia Matthaei de Cadorinis: Padua, Italy, 1658.

50. Billard, C.M. Traité des Maladies des Enfants Nouveau-Nés, et à la Mamelle. [Treatise of Diseases of Newborn and Breastfed Childrens]; Eight Edition with Notes from Dr. Ollivier d'Angers; Baillière: Brussels, Belgium, 1835; p. 868.

51. Engström, D. Genitalblutung bei einem neugeborenen Mädchen [Genital bleeding in a Newborn Girl]. Finska Läkaresällsk 1894, $38,391$.

52. Busey. Blutiger Ausfluß aus der Vulva und Vagina bei Neugeborenen [Bloody discharge from the vulva and vagina by newborns]. Arch. Kinderheilkunde 1894, 19, 104.

53. Ferraresi, C. Metrorragia delle neonate [Newborns' metrorrhagia]. Atti Soc. Ital. Ostetr. Ginecol. 1901, 8, $115-116$.

54. Vetere, G. Sulla mestruzione infantile. Sua eziologia e cura chirurgica. [On infantile menstruation. Its etiology and treatment]. Arch. Ostetr. Ginecol. 1897, 10, 602-614.

55. Kouindjy, M. Trois cas de menstruation chez les nouveau-nés. Arch. Méd. Enfants 1900, 3, 677-679.

56. Jardine, R. Menstruation in a New-Born Infant. BMJ 1897, 2, 652.

57. Alfieri, E. A proposito delle emorragie genitali delle neonate [On genital hemorrhages of newborns]. Rendiconti della Associazione Medico-Chirurgica di Parma 1901, 2, 3.

58. Zappert, J. Über Genitalblutungen neugeborener Mädchen [About genital bleeding in newborn girls]. Wien. Mediz Wochensch 1903, 53, 1478-1479.

59. Purefoy, R.D.; Castor, P. ART. XIV. Clinical Report of the Rotunda Hospital for Year ending November 1, 1901, Menstruation in infants. Dublin J. Med. Sci. 1902, 113, 340. [CrossRef]

60. Dewar, T.W. Vaginal Hemorrhage and Milky Secretion from Mammae in Infant. BMJ 1908, I, 1423.

61. Williams, W.R. Congenital Menstruation, Ovulation Lactation, and Congenital Puberty. BMJ 1901, 3, 640.

62. McWalter, J.C. Menstruation in an Infant. BMJ 1907, 2, 1736.

63. Drake, F.I. Vaginal hemorrhage in the newborn. J. Am. Med. Assoc. 1907, 49, 775. [CrossRef]

64. Holt, L.E. The Diseases of Infancy and Childhood for the Use of Students and Practitioners of Medicine; D. Appleton and Co.: New York, NY, USA, 1897; p. 104.

65. Novak, E. Menstruation and Its Disorders; D. Appleton: New York, NY, USA, 1921; pp. 121-124.

66. Schukowsky, H. Blutungen aus den Genital-Organen bei Neugeborenen Mädchen [Bleeding from the genital organs in newborn girls]. St. Petersburger Med. Wochenschr. 1902, 27, 79.

67. Krönig, F. Metrorrhagia neonatorum [Metrorrhagia in neonates]. Münchener Med. Wochenschr. 1912, $59,280$.

68. Zacharias, E. Genitalblutungen Neugeborener Mädchen [Genital bleeding in newborn girls]. Med. Klin. Berl. 1914, $10,1645$.

69. Halban, J. Schwangerschaftsreaktionen der fötalen Organe und ihre puerperale Involution [Changes during pregnancy of fetal organs and their involution during puerperium]. Z. Geburtshilfe Gynäkol. 1904, 53, 191-231.

70. Lisi, F. Metrorrhagia neonatorum [metrorrhagia in neonates]. Arch. Ital. Anat. Istol. Patol. 1930, 2, $423-428$.

71. Andreoli, C.; Simonetta, R. Incidencia de la Hemorragia Uterina en la Neonata [Incidence of uterine hemorrhage in the neonate]. Dia Med. 1960, 26, 976-977. 
72. Levy, J.M.; Rosenthal, R.; Dellenbach, P.; Pequenot, J.P. Crise génitale du nouveau-né. Répercussion de certains facteurs maternels ou gravidiques sur la fréquence des métrorragies néonatales [Genital crisis in the newborn. Repercussion of certain maternal or pregnancy factors on the frequency of neonatal metrorrhagia]. Arch. Fr. Pediatr. 1964, 21, 819-827. [PubMed]

73. Zubovich, V.K. Article in Russian [Effect of sexual crisis on the state of the newborn in the 1st days of life]. Akush. Ginekol. (Moskwa) 1968, 44, 67-69.

74. Kaiser, R.; Grässel, G. Frequenz und Stärke der uterinen Neugeborenenblutung. [Incidence and intensity of uterine bleeding in the neonate]. Geburtsh. Frauenheilk. 1974, 34, 644-648.

75. Huber, A. Die The frequency of physiologic vaginal bleeding of newborn infants. Zent. Gynakol. 1976, 98, 1017-1020.

76. Berić, B.M.; Prodanović, Z.; Mitrović, M.; Ćurčić, O. Uterino krvavljenje u novorodene dece [Uterine hemorrhage in newborns]. Jugosl. Ginekol. Perinatol. 1985, 25, 89-91. [PubMed]

77. Doleris, M. À propos des saignements génitaux chez les nouveau-nés [About genital bleeding in newborns]. Gazette Hebdom Med. Chir. 1898. Reported in Zentralblatt Gynäkol. 1898, 42, 1168.

78. Frew, W. Menstruation in a Newly-Born Female Child with Convulsions. BMJ 1902, 1, 1536.

79. Halban, J. Österreichisches Biographisches Lexikon 1815-1950 [Austrian Biographical Lexicon 1815-1950]. Vienna Austrian Acad. Sci. 1959, 2, 158.

80. Halban, J. Über fötale Menstruation und ihre Bedeutung [About Fetal Menstruation and Its Meaning]; Berliner Klin Wochenschrift. VII.76 (Versammlung Deutscher Naturforscher und Ärzte in Breslau): Heidelberg, Germany, 1904; Volume 48, p. 1255.

81. Rosa, P. Endocrinologie Sexuelle du Foetus Féminin [Sexual Endocrinology of the Female Fetus]; Masson et Cie: Paris, France, 1955; Volume 1, pp. 262-272.

82. Ober, W.B.; Bernstein, J. Observations on the endometrium and ovary in the newborn. Pediatrics 1955, 16, 445-460. [CrossRef] [PubMed]

83. Philipp, E. Schwangerschaftsveränderungen beim Neugeborenen [Changes in the newborn produced by pregnancy]. Arch. Gynäkol. 1938, 166, 185-187. [CrossRef] 